University of Nebraska - Lincoln

DigitalCommons@University of Nebraska - Lincoln

Roman L. Hruska U.S. Meat Animal Research

U.S. Department of Agriculture: Agricultural Center

Research Service, Lincoln, Nebraska

2007

\title{
Comparative Response of Rams and Bulls to Long-Term Treatment with Gonadotropin-Releasing Hormone Analogs
}

\author{
H. Jiménez-Severiano \\ INIFAP-SAGARPA \\ M. J. D'Occhio \\ University of Queensland \\ D. D. Lunstra \\ USDA-ARS
}

M. L. Mussard

Ohio State University - Main Campus

T. L. Davis

Colorado State University - Fort Collins

See next page for additional authors

Follow this and additional works at: https://digitalcommons.unl.edu/hruskareports

Jiménez-Severiano, H.; D'Occhio, M. J.; Lunstra, D. D.; Mussard, M. L.; Davis, T. L.; Enright, W. J.; and Kinder, J. E., "Comparative Response of Rams and Bulls to Long-Term Treatment with Gonadotropin-Releasing Hormone Analogs" (2007). Roman L. Hruska U.S. Meat Animal Research Center. 236.

https://digitalcommons.unl.edu/hruskareports/236

This Article is brought to you for free and open access by the U.S. Department of Agriculture: Agricultural Research Service, Lincoln, Nebraska at DigitalCommons@University of Nebraska - Lincoln. It has been accepted for inclusion in Roman L. Hruska U.S. Meat Animal Research Center by an authorized administrator of DigitalCommons@University of Nebraska - Lincoln. 


\section{Authors}

H. Jiménez-Severiano, M. J. D'Occhio, D. D. Lunstra, M. L. Mussard, T. L. Davis, W. J. Enright, and J. E. Kinder 


\title{
ANIMAL \\ REPRODUCTION \\ SCIENCE
}

Animal Reproduction Science 98 (2007) 204-224

www.elsevier.com/locate/anireprosci

\section{Comparative response of rams and bulls to long-term treatment with gonadotropin-releasing hormone analogs}

\author{
H. Jiménez-Severiano ${ }^{\text {a,b, } 1}$, M.J. D’Occhio ${ }^{c}$, D.D. Lunstra ${ }^{\mathrm{d}}$, \\ M.L. Mussard ${ }^{\text {a,b }}$, T.L. Davis ${ }^{a, b, 2}$, W.J. Enright ${ }^{\mathrm{e}}$, J.E. Kinder ${ }^{\mathrm{a}, \mathrm{b}, *}$ \\ ${ }^{a}$ Department of Animal Science, University of Nebraska, Lincoln, NE 68583-0908, USA \\ b Department of Animal Sciences, The Ohio State University, 2029 Fyffe Road, Columbus, OH 43210-1095, USA \\ c School of Animal Studies, The University of Queensland, Gatton, Qld 4343, Australia \\ ${ }^{\mathrm{d}}$ The U.S. Department of Agriculture, Agriculture Research Service, Roman L. Hruska, \\ U.S. Meat Animal Research Center, Clay Center, NE 68933-0166, USA \\ e Intervet International, 5830 AA Boxmeer, The Netherlands
}

Received 13 July 2005; received in revised form 14 February 2006; accepted 27 February 2006

Available online 17 April 2006

\begin{abstract}
The objective was to compare the relative response between rams and bulls in characteristics of LH, FSH and testosterone (T) secretion, during and after long-term treatment with GnRH analogs. Animals were treated with GnRH agonist, GnRH antagonist, or vehicle (Control) for 28 days. Serial blood samples were collected on day 21 of treatment, and at several intervals after treatment. Injections of natural sequence $\mathrm{GnRH}$ were used to evaluate the capacity of the pituitary to release gonadotropins during and after treatment. Treatment with GnRH agonist increased basal LH and T concentrations in both rams and bulls, with a greater relative increase in bulls. Endogenous LH pulses and LH release after administration of GnRH were suppressed during treatment with GnRH agonist. Treatment with GnRH antagonist decreased mean hormone concentrations, $\mathrm{LH}$ and $\mathrm{T}$ pulse frequency, and the release of $\mathrm{LH}$ and $\mathrm{T}$ after exogenous $\mathrm{GnRH}$, with greater relative effects in bulls. Rams previously treated with antagonist had a greater release of LH after administration of GnRH compared with control rams, while rams previously treated with agonist showed a reduced LH response. Bulls previously treated with agonist had reduced FSH concentrations and LH pulse amplitudes compared with control bulls while bulls previously treated with antagonist had greater $\mathrm{T}$
\end{abstract}

\footnotetext{
* Corresponding author. Tel.: +1 614292 3232; fax: +1 6142922929.

E-mail addresses: kinder.15@osu.edu, osborne.2@osu.edu (J.E. Kinder).

1 Present address: CENID Fisiología Animal, INIFAP-SAGARPA, Apdo, Postal 1-1168, Querétaro, Qro. CP 76001, Mexico.

2 Present address: Department of Biomedical Sciences, Colorado State University, Fort Collins, CO 80523, USA.
} 
concentrations and pulse frequency. The present study was the first direct comparison between domestic species of the response in males to treatment with GnRH analogs. The findings demonstrated that differences do occur between rams and bulls in LH, FSH and testosterone secretion during and after treatment. Also, the consequences of treatment with either GnRH analog can persist for a considerable time after discontinuation of treatment.

(C) 2006 Elsevier B.V. All rights reserved.

Keywords: Cattle; GnRH; GnRH analogs; LH; FSH; Testosterone; Male sexual function

\section{Introduction}

Treatment of males with GnRH agonists causes a down-regulation of the anterior pituitary gland that is (uniformly) associated with an absence of pulsatile secretion of LH and FSH and decreased mean concentrations of these gonadotropins in blood (Bhasin and Swerdloff, 1986). In rats (Labrie et al., 1980), dogs (Vickery et al., 1985), wild carnivores (Bertschinger et al., 2001), boars (Xue et al., 1994) rams (Fraser and Lincoln, 1980; Lincoln et al., 1986), men (Schürmeyer et al., 1984), and other primates (Vickery and McRae, 1980; Bint Akhtar et al., 1983), GnRH agonist-induced pituitary down-regulation also results in testicular atrophy and reduced secretion of testosterone (T). In contrast, bulls (D’Occhio and Aspden, 1999), deer (Lincoln, 1987), antelopes (Penfold et al., 2002), tammar wallaby (Herbert et al., 2004), and strains of mice (Wang et al., 1983) treated with GnRH agonist do not show a decrease in T secretion, and in bulls $\mathrm{T}$ secretion is actually enhanced during agonist treatment (Melson et al., 1986; Ronayne et al., 1993; D'Occhio and Aspden, 1996; Jiménez-Severiano et al., 2003a). Differences among rodent species also appear to occur in the response of males to treatment with GnRH antagonists (Sundaram et al., 1984). There have not been any studies comparing the relative effects of treatment with GnRH analogs in domestic species. The possibility remains, therefore, that apparent species differences might be related to type or dose of analog, method of administration, age or reproductive status. It is important to establish whether species differ in their response to treatment with GnRH analogs as any differences may be reflective of other more fundamental differences in reproductive endocrine mechanisms.

The aim in the present study was to undertake a detailed comparison of the patterns of gonadotropin and T secretion during treatment with a GnRH agonist or antagonist in two species that apparently show differential responses to GnRH analogs. Bulls and rams were treated with a GnRH agonist and GnRH antagonist, and characteristics of LH, FSH and T secretion were compared during and after treatment. The response of the anterior pituitary to GnRH was also compared during and after treatment with GnRH analogs.

\section{Materials and methods}

\subsection{Animals}

All protocols and procedures used were approved by the Institutional Animal Care and Use Committee at the University of Nebraska, Lincoln. Rams (1/2 Columbia, 1/4 Suffolk, 1/4 Hampshire, $n=24)$ and bulls (1/4 Hereford, 1/4 Angus, 1/4 Pinzgauer, 1/4 Red Poll, $n=24)$ were used in the experiment. Animals of both species were post-pubertal at the start of the study. For both rams and bulls, a scrotal circumference (SC) $\geq 28 \mathrm{~cm}$ and presence of sperm cells in 
the ejaculate were indicative that animals had attained puberty. At the start of the experiment, rams were $194 \pm 1$ days of age, $53.8 \pm 1.3 \mathrm{~kg}$ body weight (BW) and had a SC of $31.9 \pm 0.4 \mathrm{~cm}$. Bulls were $352 \pm 1$ days of age, $318 \pm 5 \mathrm{~kg} \mathrm{BW}$ and had a SC of $32.2 \pm 0.5 \mathrm{~cm}$. The study with rams was conducted between late fall and early winter (19 November-26 January), and the study with bulls during the spring ( 7 April-14 June). The data should not be confounded with season, because the period of the year when the ram study was conducted corresponds to the breeding season of ewes of the same genotype (Freking et al., 2000); furthermore, bulls have the greatest secretion of gonadotropins and their testes are more responsive to LH during the spring and summer as compared with other seasons of the year (Stumpf et al., 1993; Jiménez-Severiano et al., 2003b).

\subsection{GnRH agonist and antagonist}

The GnRH agonist used was azagly-nafarelin ([D-Nal $(2)^{6}$, aza-Gly $\left.{ }^{10}\right] \mathrm{GnRH}$; Intervet International bv. Boxmeer, The Netherlands) and the GnRH antagonist was cetrorelix (SB-75; [AcD-Nal $(2)^{1}$, D-Phe $\left.\left.(4 \mathrm{Cl})^{2}, \mathrm{D}-\mathrm{Pal}(3)^{3}, \mathrm{D}^{-\mathrm{Cit}^{6}}{ }, \mathrm{D}-\mathrm{Ala}{ }^{10}\right] \mathrm{GnRH}\right)$. The latter was synthesized by Dr. Gautam Sarath (Peptide Synthesis and Sequencing Facility, University of Nebraska, Lincoln, $\mathrm{NE}$ ). Natural sequence GnRH (referred to as GnRH thereafter) was obtained from a commercial source (Sigma Chemical Co., St. Louis, MO).

\subsection{Treatments}

The following description of treatments applies for animals of both species, unless indicated otherwise. Animals were allocated at random with stratification into treatment groups based on SC and BW to one of the following treatments $(n=8)$ : Control, received daily s.c. $1 \mathrm{ml}$ of a $5 \%(w / v)$ mannitol solution. GnRH agonist, received continuous administration of azaglynafarelin in a solution of sodium chloride $0.15 \mathrm{M}$, at $1 \mu \mathrm{g} / \mathrm{kg}$ BW per day, using Alzet mini osmotic pumps (model 2ML4, Alza Corp. Palo Alto, CA), as previously described (JiménezSeveriano et al., 2003a); this dose was chosen based on previous studies in bull calves (Ronayne et al., 1993; Jiménez-Severiano et al., 2003a). GnRH antagonist, received daily s.c. cetrorelix in a solution of $5 \%(\mathrm{w} / \mathrm{v})$ mannitol, at $10 \mu \mathrm{g} / \mathrm{kg} \mathrm{BW}$ per day; this dose and via of administration suppresses pulses of LH within $4 \mathrm{~h}$ and the effect lasts for at least $24 \mathrm{~h}$ in cows (Peters et al., 1994), but when this dose is reduced to $5 \mu \mathrm{g} / \mathrm{kg} \mathrm{BW}$ per day, pulse suppression is not consistent (our unpublished data); subcutaneous administration was chosen because the amount of cetrorelix needed for cattle, makes the solution viscosity such that the mini osmotic pumps cannot be used for administration (our unpublished data). All treatments were applied for 28 days.

\subsection{Hormone secretion during treatment}

Blood samples were taken from all animals at $0,2,4,6,8,12,16,20$, and $24 \mathrm{~h}$ relative to the start of treatments. Serial blood samples ( $20 \mathrm{~min}$ intervals for $24 \mathrm{~h}$ ) were taken on day 21 of treatment. Each animal was administered GnRH i.v. on day $22(1 \mathrm{ng} / \mathrm{kg} \mathrm{BW})$, day $24(10 \mathrm{ng} / \mathrm{kg}$ $\mathrm{BW})$ and day $26(100 \mathrm{ng} / \mathrm{kg} \mathrm{BW})$. On these occasions blood samples were taken at $-0.5,0,0.5$, $1,2,3,4,5$, and $6 \mathrm{~h}$ relative to the time of $\mathrm{GnRH}$ administration. Additionally, single samples were collected from all animals by jugular puncture, between 0800 and $1000 \mathrm{~h}$, two times a week during the 28-day treatment period. 


\subsection{Hormone secretion after treatment}

After cessation of the 28-day treatment period, each treatment was divided into two groups of four animals each. To evaluate the hormone secretory patterns after treatment, animals in one subgroup of each treatment group received no further treatment and were serially sampled as described above on days 1, 10, 20, 30, and 40 after discontinuing GnRH analog treatment. To evaluate the return of sensitivity of the pituitary-testis axis to $\mathrm{GnRH}$, the second subgroup of rams and bulls received i.v. $100 \mathrm{ng} \mathrm{GnRH/kg} \mathrm{BW}$ on days 1, 10, 20, 30, and 40 after GnRH analog treatment. Blood samples relative to $\mathrm{GnRH}$ were taken as described above.

Animals were fitted with indwelling jugular catheters one day before the start of each serial collection period and GnRH administration. Catheters were comprised of medical vinyl tubing (i.d.: 0.86 mm, o.d.: $1.32 \mathrm{~mm}$; Scientific Commodities Inc. Lake Havasu City, AZ) for rams, and Tygon ${ }^{\circledR}$ flexible plastic tubing (i.d.: $1.27 \mathrm{~mm}$, o.d.: $2.29 \mathrm{~mm}$; Norton Performance Plastics, Akron, $\mathrm{OH})$ for bulls.

\subsection{Hormone radioimmunoassays}

Concentrations of LH were determined in all samples by a double antibody RIA (Wolfe et al., 1989). The limit of detection was $140 \mathrm{pg} / \mathrm{ml}$ for both cattle and sheep assays. The intra- and inter-assay coefficients of variation were 6.1 and $9.8 \%$, respectively, for sheep samples, and 3.7 and $11.4 \%$, respectively, for cattle samples.

Concentrations of FSH were determined in samples every $2 \mathrm{~h}$ from the serial bleedings and in all the other samples collected during the experiment. Determinations were made with a double antibody RIA (Wolfe et al., 1989), modified so the assay could be completed in 3 days. Briefly, $200 \mu \mathrm{l}$ of serum were used, diluted with $300 \mu \mathrm{l}$ of phosphate-buffered saline with $0.1 \%$ (w/v) gelatin (PBS-gel; pH: 7.4). On day 1, the primary antibody (1:10,000 dilution in $200 \mu \mathrm{l} \mathrm{PBS-gel)}$ was added to all tubes, except total count and non-specific binding tubes, and incubated for $24 \mathrm{~h}$ at $4{ }^{\circ} \mathrm{C}$. On day 2 , the labeled hormone $(20,000 \mathrm{cpm}$ in $100 \mu \mathrm{l}$ PBS-gel $)$ was added to all assay tubes, and incubated for an additional 24 -h period at $4{ }^{\circ} \mathrm{C}$. On day 3, $100 \mu \mathrm{l}$ of a secondary antibody suspension, containing $15 \%$ (v/v) anti-rabbit gamma globulin, $0.5 \%$ (v/v) normal rabbit serum, $84.5 \%(\mathrm{v} / \mathrm{v})$ PBS-gel were added to all tubes except for total counts, and incubated for $1 \mathrm{~h}$ at room temperature. The reaction was stopped by adding $2 \mathrm{ml}$ of cold PBS to all tubes except for total counts, and centrifuged at $2000 \times g$ for $45 \mathrm{~min}$ at $4{ }^{\circ} \mathrm{C}$. Following centrifugation, tubes were decanted and inverted to drain over absorbent paper. The limit of detection was $200 \mathrm{pg} / \mathrm{ml}$ for bovine and $156 \mathrm{pg} / \mathrm{ml}$ for ovine assays. The intra- and inter-assay coefficients of variation were 3.5 and $8.2 \%$ for sheep samples and 3.6 and $4.6 \%$ for cattle samples, respectively.

The RIA for bovine FSH was validated as follows. Ten different bovine serum samples were assayed at 100, 200 and $300 \mu$ l. These serial dilutions generated binding inhibition curves that paralleled the FSH standard curve. Furthermore, the average ratios \pm S.D. and correlation of the FSH concentrations obtained between the different pair of volumes were $1.08 \pm 0.12(r=0.98)$, $1.12 \pm 0.1(r=0.98)$, and $1.2 \pm 0.14(r=0.98)$, respectively, for $100 \mu l$ versus $200 \mu l, 200 \mu l$ versus $300 \mu \mathrm{l}$, and $100 \mu \mathrm{l}$ versus $300 \mu \mathrm{l}$. Three pools of cattle serum were used to evaluate recovery of $0.08,0.16,0.32,0.64$, and $1.28 \mathrm{ng}$ of added FSH. Recovery averaged ( \pm S.D.) $105 \pm 2.5 \%$.

The RIA for ovine FSH was validated as follows. Two different sheep serum pools containing lesser or greater concentrations of FSH were assayed at 100, 200 and $400 \mu \mathrm{l}$. Parallelism was evaluated by using the Allfit program (De Lean et al., 1978). Slopes and end points of standard curves and serum dilutions were not different $(P=0.51)$. The average ratio \pm S.D. and correlation 
between pairs were $1.24 \pm 0.09(r=1), 1.14 \pm 0.14(r=1)$, and $1.43 \pm 0.27(r=1)$, respectively, for $100 \mu \mathrm{l}$ versus $200 \mu \mathrm{l}, 200 \mu \mathrm{l}$ versus $400 \mu \mathrm{l}$, and $100 \mu \mathrm{l}$ versus $400 \mu \mathrm{l}$. Two pools of sheep serum were used to evaluate recovery of $0.04,0.32$, and $2.56 \mathrm{ng}$ of added FSH. Recovery averaged ( \pm S.D.) $102 \pm 6.2 \%$. Furthermore, the sheep 3-day assay was compared with a 5-day assay previously validated in our laboratory (Wolfe et al., 1989). Twelve different sheep serum samples were assayed with both systems, and the standard curves and concentrations compared. Slopes and end points of standard curves were not different $(P=0.56)$. The average ratio \pm S.D. between FSH concentrations obtained with the 3 - and the 5-day systems was $0.83 \pm 0.04(r=0.98)$.

Concentrations of $\mathrm{T}$ were determined in every other serial sample that was collected and in all the other samples collected during the experiment, by a double antibody RIA, previously validated for sheep (Dayalu and Kittok, 1996) and cattle (Jiménez-Severiano et al., 2003a) sera. The limit of detection was $50 \mathrm{pg} / \mathrm{ml}$ for both sheep and cattle assays. The intra- and inter-assay coefficients of variation were 6.4 and $7.6 \%$ for sheep samples and 6.9 and $8.1 \%$ for cattle samples, respectively.

\subsection{Hormone secretory patterns and statistical analyses}

Secretory patterns of $\mathrm{LH}$ and T were evaluated for mean and basal concentrations $(\mathrm{ng} / \mathrm{ml})$, and for pulse frequency (pulses/24h) and amplitude (ng/ml), using computer algorithms (Merriam and Wachter, 1982; Pulsar software modified for IBM-PC by J.F. Gitzen and V.D. Ramirez). The $G$-values used were: $G(1)=3.8, G(2)=2.6, G(3)=1.9, G(4)=1.5$, and $G(5)=1.2$. The assay standard deviation used in the algorithm was modeled as a quadratic function of the dose for each hormone and species. For FSH, mean concentration was the only variable evaluated. With the GnRH administration, amplitude of the release ( $\Delta$ values) for LH, T and FSH was calculated by substracting the hormone concentration before $\mathrm{GnRH}$ administration from the maximum concentration after administration.

All data were analyzed separately for each species and the effects of treatments were compared with the control group within each species. Data for FSH concentration and for LH and T secretory pattern variables on day 21 of treatment were analyzed using the GLM procedure of SAS (1990), as a completely randomized design (CRD). Amplitude of the release of LH, T, and FSH after graded doses of GnRH during the treatment was analyzed as a CRD with a $3 \times 3$ factorial treatment design, where the factors were three treatments and three doses. Data after cessation of treatment were analyzed as a CRD, using the MIXED procedure of SAS for repeated measures (Littell et al., 1996), with the statement repeated, the options sub= animal (treatment), and autoregressive (1) covariance structure within animal. Treatment, day, and treatment $\times$ day interaction were included in the model. The PDIFF option of SAS was used to compare least square means among treatments. When necessary, variables were $\log _{10}(Y+1)$ transformed so that the assumptions of the analysis of variance were valid. $P$-values $<0.05$ were considered significant, unless indicated otherwise in the tables and figures. A tendency to be significant was considered with $P$-values between 0.05 and 0.10 .

\section{Results}

\subsection{Initial release of $L H, T$, and FSH after GnRH analog administration}

\subsubsection{Rams}

During the first $24 \mathrm{~h}$ of treatment, concentrations of $\mathrm{LH}$ in control rams varied between 0.8 and $1.6 \mathrm{ng} / \mathrm{ml}$ (Fig. 1a). Concentrations of $\mathrm{LH}$ in rams treated with $\mathrm{GnRH}$ agonist reached 
Rams

Bulls


Time (days) of treatment

Fig. 1. Mean ( \pm S.E.M.) serum concentrations of LH, testosterone, and FSH for rams (panels a-c) and bulls (panels d-f). Rams and bulls were treated with vehicle (control; open circles), or with GnRH agonist (open squares), or GnRH antagonist (closed circles) for 28 days. Notice the different scale for testosterone for rams and bulls $(n=8$ at each time point).

$47 \pm 7 \mathrm{ng} / \mathrm{ml}, 4 \mathrm{~h}$ after starting the treatment. Thereafter, concentrations decreased during the next $20 \mathrm{~h}$ without returning to pre-treatment concentrations. In rams treated with GnRH antagonist, LH concentrations were maintained at less than $0.7 \mathrm{ng} / \mathrm{ml}$. During the first $24 \mathrm{~h}$ of treatment, T concentrations in control rams varied from 1 to $3.3 \mathrm{ng} / \mathrm{ml}$ (Fig. 1b). In rams treated with GnRH agonist, maximal values $(8.32 \pm 1.0 \mathrm{ng} / \mathrm{ml})$ were attained $4 \mathrm{~h}$ after inserting the pumps, with values decreasing during the next $20 \mathrm{~h}$ without returning to pre-treatment concentrations. Concentration of $\mathrm{T}$ increased again until day 5 of treatment, and decreased to pre-treatment values by day 19 . Concentrations of $\mathrm{T}$ in rams treated with $\mathrm{GnRH}$ antagonist were maintained at less than $0.8 \mathrm{ng} / \mathrm{ml}$ for about 2 days; after which concentrations were similar to those in control rams. 
Table 1

Averages ( \pm S.E.M.) for variables of $\mathrm{LH}$ and testosterone $(\mathrm{T})$ secretion in rams on day 21 of treatment

\begin{tabular}{llllll}
\hline Hormone & Treatment $^{\mathrm{a}}$ & Mean $(\mathrm{ng} / \mathrm{ml})$ & Basal $(\mathrm{ng} / \mathrm{ml})$ & $\begin{array}{l}\text { Pulse frequency } \\
(\mathrm{pulses} / 24 \mathrm{~h})\end{array}$ & $\begin{array}{l}\text { Pulse amplitude } \\
(\mathrm{ng} / \mathrm{ml})\end{array}$ \\
\hline $\mathrm{LH}$ & Control & $1.03 \pm 0.16 \mathrm{e}, \mathrm{f}$ & $0.77 \pm 0.06 \mathrm{~b}$ & $2.67 \pm 0.25 \mathrm{a}$ & $2.60 \pm 1.11 \mathrm{e}$ \\
& Agonist & $1.14 \pm 0.05 \mathrm{e}$ & $1.14 \pm 0.05 \mathrm{a}$ & $0.00 \mathrm{~b}$ & - \\
& Antagonist & $0.76 \pm 0.04 \mathrm{f}$ & $0.74 \pm 0.05 \mathrm{~b}$ & $2.00 \pm 0.5 \mathrm{a}$ & $0.48 \pm 0.07 \mathrm{f}$ \\
$\mathrm{T}$ & Control & $1.49 \pm 0.15 \mathrm{e}, \mathrm{f}$ & $0.70 \pm 0.07 \mathrm{~b}$ & $2.67 \pm 0.25 \mathrm{a}$ & $3.82 \pm 0.71$ \\
& Agonist & $2.25 \pm 0.42 \mathrm{e}$ & $2.25 \pm 0.43 \mathrm{a}$ & $0.00 \mathrm{~b}$ & - \\
& Antagonist & $0.94 \pm 0.17 \mathrm{f}$ & $0.54 \pm 0.05 \mathrm{~b}$ & $2.50 \pm 0.69 \mathrm{a}$ & $2.36 \pm 0.56$ \\
\hline
\end{tabular}

Means with different letters within variable and hormone are different: (a,b) $P<0.001$; (e,f) $P<0.05$.

${ }^{a}$ Rams were treated for 28 days with vehicle (control), or with GnRH agonist, or GnRH antagonist $(n=8)$.

Concentrations of FSH in rams treated with GnRH agonist reached $3.69 \pm 0.33 \mathrm{ng} / \mathrm{ml}, 4 \mathrm{~h}$ after inserting the pumps (Fig. 1c), and decreased during the next $20 \mathrm{~h}$ to concentrations $(1.74 \pm 0.08 \mathrm{ng} / \mathrm{ml})$ still above control rams $(1.36 \pm 0.07 \mathrm{ng} / \mathrm{ml})$. In control rams and rams treated with $\mathrm{GnRH}$ antagonist, FSH remained at concentrations below $1.5 \mathrm{ng} / \mathrm{ml}$ during the first $24 \mathrm{~h}$ of treatment.

\subsubsection{Bulls}

During the first $24 \mathrm{~h}$ of treatment, $\mathrm{LH}$ and $\mathrm{T}$ concentrations in control bulls ranged from 1.52 to $3.12 \mathrm{ng} \mathrm{LH} / \mathrm{ml}$ (Fig. 1d) and 0.99 to $9.01 \mathrm{ng} \mathrm{T/ml} \mathrm{(Fig.} \mathrm{1e).} \mathrm{Bulls} \mathrm{treated} \mathrm{with} \mathrm{GnRH} \mathrm{agonist}$ had maximal LH concentrations of $61.65 \pm 12.39 \mathrm{ng} / \mathrm{ml}$, between 2 and $4 \mathrm{~h}$, which then decreased between 16 and $24 \mathrm{~h}$ to concentrations that remained greater $(3.78 \pm 0.21 \mathrm{ng} / \mathrm{ml})$ than those of control bulls $(1.59 \pm 0.16 \mathrm{ng} / \mathrm{ml})$. Maximal T concentrations of $13.97 \pm 0.74 \mathrm{ng} / \mathrm{ml}$ were reached by $2 \mathrm{~h}$ after initiation of treatment and then decreased to concentrations that were similar to pretreatment values by $16 \mathrm{~h}$. Thereafter, $\mathrm{T}$ increased again until day 18 of treatment. In bulls treated with GnRH antagonist, $\mathrm{LH}$ and T were maintained at concentrations less than $1.5 \mathrm{ng} \mathrm{LH} / \mathrm{ml}$ and less than $2 \mathrm{ng} \mathrm{T} / \mathrm{ml}$ during the treatment.

Maximal FSH concentration in bulls treated with GnRH agonist was $4.32 \pm 0.47 \mathrm{ng} / \mathrm{ml}$ (Fig. 1f), which was attained by $4 \mathrm{~h}$ after inserting the pumps. During the next $8 \mathrm{~h}, \mathrm{FSH}$ returned to concentrations similar to control bulls $(1.94 \pm 0.12 \mathrm{ng} / \mathrm{ml})$ and bulls treated with $\mathrm{GnRH}$ antagonist $(1.76 \pm 0.11 \mathrm{ng} / \mathrm{ml})$.

\subsection{Secretory characteristics for $L H$}

\subsubsection{Rams}

Data for characteristics of LH secretory patterns on day 21 of treatment in rams are included in Table 1. Mean LH concentration in rams treated with GnRH antagonist tended to be less than in control rams and was less than in rams treated with GnRH agonist. Basal LH concentration was $0.4 \mathrm{ng} / \mathrm{ml}$ greater in rams treated with GnRH agonist, compared with the other groups. No LH pulses were detected in rams treated with the GnRH agonist. Numbers of LH pulses in control rams and rams treated with GnRH antagonist did not differ, but the amplitude of pulses was 5.4 times greater in the control rams.

After the discontinuation of treatments in rams (Table 2), the effects of treatment and treatment $\times$ day interaction were not significant for mean and basal concentrations of LH. Pulse frequency of LH was less in rams treated with GnRH agonist only on day 1 after cessation 
Table 2

Averages $( \pm$ S.E.M.) for variables of LH secretion in rams on days 1-40 after the discontinuation of treatment

\begin{tabular}{clllll}
\hline Day & Treatment & Mean $(\mathrm{ng} / \mathrm{ml})$ & Basal $(\mathrm{ng} / \mathrm{ml})$ & $\begin{array}{l}\text { Pulse frequency } \\
\text { (pulses/24h) }\end{array}$ & $\begin{array}{l}\text { Pulse amplitude } \\
(\mathrm{ng} / \mathrm{ml})\end{array}$ \\
\hline 1 & & & $5.00 \pm 0.58 \mathrm{e}$ & $2.84 \pm 0.63 \mathrm{e}$ \\
& Control & $1.32 \pm 0.27$ & $0.78 \pm 0.12$ & $0.75 \pm 0.75 \mathrm{f}$ & $1.49 \mathrm{~b}$ \\
& Agonist & $0.82 \pm 0.09$ & $0.78 \pm 0.07$ & $4.75 \pm 0.95 \mathrm{e}$ & $0.82 \pm 0.16 \mathrm{f}$ \\
10 & Antagonist & $0.99 \pm 0.06$ & $0.86 \pm 0.03$ & $6.12 \pm 0.98$ \\
& Control & $1.24 \pm 0.2$ & $0.72 \pm 0.13$ & $6.00 \pm 1.35$ & $3.04 \pm 0.37$ \\
& Agonist & $1.02 \pm 0.1$ & $0.68 \pm 0.11$ & $3.75 \pm 0.48$ & $2.75 \pm 0.69$ \\
20 & Antagonist & $1.28 \pm 0.16$ & $0.77 \pm 0.03$ & $5.50 \pm 0.65$ & $2.70 \pm 0.39 \mathrm{f}$ \\
& Control & $1.34 \pm 0.14$ & $0.82 \pm 0.05$ & $6.25 \pm 1.25$ & $3.01 \pm 0.62 \mathrm{e}, \mathrm{f}$ \\
& Agonist & $1.40 \pm 0.15$ & $0.80 \pm 0.06$ & $5.00 \pm 2.12$ & $3.82 \pm 0.91 \mathrm{e}, \mathrm{f}$ \\
30 & Antagonist & $1.34 \pm 0.13$ & $0.88 \pm 0.02$ & $4.25 \pm 0.48$ & $4.38 \pm 0.82 \mathrm{e}$ \\
& Control & $1.34 \pm 0.24$ & $0.73 \pm 0.08$ & $4.89 \pm 0.67$ & $2.27 \pm 1.43 \mathrm{f}$ \\
& Agonist & $1.21 \pm 0.15$ & $0.76 \pm 0.14$ & $4.75 \pm 1.38$ & $4.87 \pm 1.32 \mathrm{e}$ \\
40 & Antagonist & $1.30 \pm 0.16$ & $0.84 \pm 0.05$ & $6.25 \pm 0.48$ & $4.00 \pm 0.65 \mathrm{e}, \mathrm{f}$ \\
& Control & $1.75 \pm 0.43$ & $0.81 \pm 0.13$ & $5.82 \pm 1.53$ & $2.45 \pm 0.31 \mathrm{f}$ \\
\hline
\end{tabular}

Means with different letters within variable and day are different: (e,f) $P<0.05$.

a Rams were treated for 28 days with vehicle (control), or with GnRH agonist, or GnRH antagonist ( $n=4$ at each day of evaluation).

b The standard error could not be calculated.

of treatments. Rams previously treated with GnRH antagonist had a similar frequency of LH pulses as control rams from 1 day after cessation of treatments, but on days 1 and 40, LH pulse amplitude in the antagonist-treated rams was less compared with control rams.

\subsubsection{Bulls}

Table 3 contains data for the characteristics of LH secretory patterns in bulls on day 21 of treatment. Bulls treated with GnRH agonist had the greatest mean and basal LH concentrations, with differences in basal $\mathrm{LH}$ being approximately $1 \mathrm{ng} / \mathrm{ml}$ greater than the other groups. Bulls treated with GnRH antagonist had a lesser mean, but similar basal concentration of LH as control

Table 3

Averages ( \pm S.E.M.) for variables of $\mathrm{LH}$ and testosterone $(\mathrm{T})$ secretion in bulls on day 21 of treatment

\begin{tabular}{llrrrc}
\hline Hormone & Treatment $^{\mathrm{a}}$ & Mean $(\mathrm{ng} / \mathrm{ml})$ & Basal $(\mathrm{ng} / \mathrm{ml})$ & $\begin{array}{l}\text { Pulse frequency } \\
\text { (pulses/24h) }\end{array}$ & $\begin{array}{l}\text { Pulse amplitude } \\
(\mathrm{ng} / \mathrm{ml})\end{array}$ \\
\hline $\mathrm{LH}$ & Control & $1.55 \pm 0.13 \mathrm{~b}$ & $1.17 \pm 0.08 \mathrm{~b}$ & $2.50 \pm 0.53 \mathrm{a}$ & $4.11 \pm 0.43 \mathrm{a}$ \\
& Agonist & $2.20 \pm 0.11 \mathrm{a}$ & $2.16 \pm 0.11 \mathrm{a}$ & $0.88 \pm 0.30 \mathrm{~b}$ & $1.23 \pm 0.16 \mathrm{~b}$ \\
& Antagonist & $1.08 \pm 0.07 \mathrm{c}$ & $1.08 \pm 0.07 \mathrm{~b}$ & $0.00 \mathrm{~b}$ & - \\
$\mathrm{T}$ & Control & $3.09 \pm 0.48 \mathrm{~b}$ & $0.93 \pm 0.13 \mathrm{~b}$ & $2.62 \pm 0.53 \mathrm{a}$ & $12.43 \pm 2.62 \mathrm{e}$ \\
& Agonist & $17.71 \pm 1.63 \mathrm{a}$ & $17.66 \pm 1.61 \mathrm{a}$ & $0.50 \pm 0.27 \mathrm{~b}$ & $6.06 \pm 1.53 \mathrm{f}$ \\
& Antagonist & $0.42 \pm 0.09 \mathrm{c}$ & $0.42 \pm 0.09 \mathrm{c}$ & $0.00 \mathrm{~b}$ & - \\
\hline
\end{tabular}

Means with different letters within variable and hormone are different: (a,b,c) $P<0.001$; (e,f) $P<0.05$.

a Bulls were treated for 28 days with vehicle (control), or with GnRH agonist, or GnRH antagonist $(n=8)$. 
Table 4

Averages ( \pm S.E.M.) for variables of LH secretion in bulls on days 1-40 after the discontinuation of treatment

\begin{tabular}{clllll}
\hline Day & Treatment & Mean $(\mathrm{ng} / \mathrm{ml})$ & Basal $(\mathrm{ng} / \mathrm{ml})$ & $\begin{array}{l}\text { Pulse frequency } \\
\text { (pulses } / 24 \mathrm{~h})\end{array}$ & $\begin{array}{l}\text { Pulse amplitude } \\
(\mathrm{ng} / \mathrm{ml})\end{array}$ \\
\hline 1 & Control & $1.23 \pm 0.10 \mathrm{e}$ & $0.88 \pm 0.14 \mathrm{e}, \mathrm{f}$ & $4.00 \pm 0.41 \mathrm{a}$ & $3.04 \pm 0.41$ \\
& Agonist & $1.12 \pm 0.09 \mathrm{e}$ & $1.13 \pm 0.09 \mathrm{e}$ & $0.00 \mathrm{~b}$ & - \\
& Antagonist & $0.62 \pm 0.09 \mathrm{f}$ & $0.62 \pm 0.09 \mathrm{f}$ & $0.00 \mathrm{~b}$ & $3.99 \pm 0.27 \mathrm{a}$ \\
10 & Control & $1.54 \pm 0.23 \mathrm{e}$ & $0.98 \pm 0.12 \mathrm{j}, \mathrm{k}$ & $4.25 \pm 1.11$ & $1.23 \pm 0.11 \mathrm{~b}$ \\
& Agonist & $1.00 \pm 0.03 \mathrm{f}$ & $0.86 \pm 0.02 \mathrm{k}$ & $5.00 \pm 0.82$ & $1.11 \pm 0.17 \mathrm{~b}$ \\
& Antagonist & $1.30 \pm 0.15 \mathrm{e}, \mathrm{f}$ & $1.20 \pm 0.13 \mathrm{j}$ & $6.75 \pm 2.93$ & $3.67 \pm 0.82 \mathrm{a}$ \\
20 & Control & $1.31 \pm 0.09 \mathrm{e}, \mathrm{f}$ & $0.93 \pm 0.07$ & $3.50 \pm 0.65 \mathrm{f}$ & $3.72 \pm 0.49 \mathrm{a}$ \\
& Agonist & $0.99 \pm 0.12 \mathrm{f}$ & $0.88 \pm 0.14$ & $3.25 \pm 0.48 \mathrm{f}$ & $3.82 \pm 0.32 \mathrm{a}$ \\
& Antagonist & $1.47 \pm 0.15 \mathrm{e}$ & $0.91 \pm 0.11$ & $5.75 \pm 0.63 \mathrm{e}$ & $1.26 \pm 0.35 \mathrm{~b}$ \\
30 & Control & $1.69 \pm 0.16$ & $1.34 \pm 0.16 \mathrm{j}, \mathrm{k}$ & $3.00 \pm 0.00$ & $4.71 \pm 0.98 \mathrm{a}$ \\
& Agonist & $1.72 \pm 0.22$ & $1.64 \pm 0.23 \mathrm{j}$ & $3.75 \pm 0.63$ & $3.52 \pm 0.18 \mathrm{e}$ \\
& Antagonist & $1.80 \pm 0.13$ & $1.31 \pm 0.09 \mathrm{k}$ & $4.00 \pm 0.41$ & $1.47 \pm 0.50 \mathrm{f}$ \\
& Control & $1.56 \pm 0.06$ & $1.23 \pm 0.07$ & $3.25 \pm 0.75$ & $3.54 \pm 0.81 \mathrm{e}$ \\
\hline
\end{tabular}

Means with different letters within variable and day are different or tend to be different: (a,b) $P<0.001$; (e,f) $P<0.05$; (j,k) $P<0.1$.

a Bulls were treated for 28 days with vehicle (control), or with GnRH agonist, or GnRH antagonist ( $n=4$ at each day of evaluation).

bulls. No LH pulses were detected in bulls treated with antagonist. Only five of eight bulls treated with GnRH agonist had one or two pulses. The amplitude of these pulses was 3.3-fold less compared with control bulls.

After discontinuation of treatments (Table 4), bulls treated with GnRH agonist had a lesser mean LH concentration than control bulls on day 10. In bulls treated with GnRH antagonist, mean LH concentration increased from day 1 to 30. Basal LH concentrations in bulls treated with GnRH agonist or antagonist did not differ from control bulls at any time after cessation of treatments. There were no LH pulses detected by day 1 after treatment in bulls from either GnRHanalog treated group. Bulls in both treatment groups had recovered LH pulse frequencies similar to control bulls by day 10 after treatment. A feature of LH secretion in bulls treated with GnRH antagonist was a greater frequency of pulses, and lesser amplitude pulses with many fluctuations not detected as a pulse by the algorithm used. Only on day 20 after treatment was LH pulse frequency detected to be greater in bulls treated with GnRH antagonist compared with bulls in the other groups. Bulls treated with GnRH antagonist had LH pulse amplitudes similar to control bulls by day 20, whereas LH pulse amplitudes in bulls treated with $\mathrm{GnRH}$ agonist remained lower than control bulls until day 40 after treatment.

\subsection{Secretory characteristics for $T$}

\subsubsection{Rams}

Characteristics of $\mathrm{T}$ secretory patterns on day 21 of treatment (Table 1) were very similar to LH. Rams treated with GnRH antagonist had reduced mean T concentration compared with rams treated with GnRH agonist, and tended to have lesser mean T concentrations than control 
Table 5

Averages $( \pm$ S.E.M.) for variables of testosterone secretion in rams on days $1-40$ after the discontinuation of treatment

\begin{tabular}{rlllll}
\hline Day & Treatment & Mean $(\mathrm{ng} / \mathrm{ml})$ & Basal $(\mathrm{ng} / \mathrm{ml})$ & $\begin{array}{l}\text { Pulse frequency } \\
(\text { pulses} / 24 \mathrm{~h})\end{array}$ & $\begin{array}{l}\text { Pulse amplitude } \\
(\mathrm{ng} / \mathrm{ml})\end{array}$ \\
\hline 1 & Control & $2.14 \pm 0.31$ & $0.74 \pm 0.08$ & $4.25 \pm 0.63 \mathrm{e}$ & $4.43 \pm 0.45 \mathrm{e}$ \\
& Agonist & $0.95 \pm 0.24$ & $0.72 \pm 0.24$ & $1.25 \pm 0.63 \mathrm{f}$ & $1.73 \pm 0.73 \mathrm{f}$ \\
& Antagonist & $1.71 \pm 0.28$ & $0.84 \pm 0.15$ & $4.75 \pm 0.75 \mathrm{e}$ & $2.96 \pm 0.69 \mathrm{e}, \mathrm{f}$ \\
10 & Control & $2.15 \pm 0.31$ & $0.88 \pm 0.22$ & $5.50 \pm 1.19 \mathrm{j}$ & $4.01 \pm 0.69$ \\
& Agonist & $1.66 \pm 0.20$ & $0.57 \pm 0.07$ & $3.50 \pm 0.29 \mathrm{k}$ & $4.58 \pm 0.62$ \\
& Antagonist & $2.07 \pm 0.36$ & $0.73 \pm 0.18$ & $3.75 \pm 0.48 \mathrm{j}, \mathrm{k}$ & $4.55 \pm 0.36$ \\
& Control & $2.43 \pm 0.42$ & $1.02 \pm 0.16$ & $4.50 \pm 0.50$ & $4.31 \pm 0.66 \mathrm{f}$ \\
& Agonist & $2.34 \pm 0.72$ & $0.82 \pm 0.26$ & $3.75 \pm 1.49$ & $6.26 \pm 0.54 \mathrm{e}$ \\
30 & Antagonist & $2.04 \pm 0.29$ & $0.78 \pm 0.08$ & $3.50 \pm 0.29$ & $4.71 \pm 0.77 \mathrm{f}$ \\
& Control & $2.33 \pm 0.21$ & $0.84 \pm 0.16$ & $5.17 \pm 0.67$ & $4.82 \pm 0.12 \mathrm{j}$ \\
& Agonist & $1.68 \pm 0.22$ & $0.71 \pm 0.14$ & $4.50 \pm 0.96$ & $3.62 \pm 0.63 \mathrm{j}, \mathrm{k}$ \\
40 & Antagonist & $1.99 \pm 0.27$ & $0.92 \pm 0.17$ & $5.25 \pm 0.48$ & $3.13 \pm 0.29 \mathrm{k}$ \\
& Control & $2.67 \pm 0.19$ & $0.97 \pm 0.08$ & $4.95 \pm 1.15$ & $5.29 \pm 0.96 \mathrm{e}$ \\
& Agonist & $2.07 \pm 0.24$ & $0.78 \pm 0.08$ & $4.50 \pm 0.65$ & $4.34 \pm 0.33 \mathrm{e}, \mathrm{f}$
\end{tabular}

Means with different letters within variable and day are different or tend to be different: (e,f) $P<0.05$; (j,k) $P<0.1$.

${ }^{a}$ Rams were treated for 28 days with vehicle (control), or with GnRH agonist, or GnRH antagonist $(n=4$ at each day of evaluation).

rams. Treatment with GnRH agonist increased basal T concentration 3.2-fold compared with the control group and suppressed the number of pulses. Frequency and amplitude of T pulses were not affected by treatment with GnRH antagonist compared with control rams.

After cessation of treatment, the effects of treatment and treatment $\times$ day interaction were not significant for mean and basal concentrations of $\mathrm{T}$ (Table 5). Frequency of $\mathrm{T}$ pulses in rams treated with GnRH agonist was less compared with control rams on day 1 and tended to be less on day 10. Amplitude of $\mathrm{T}$ pulses in rams treated with GnRH agonist increased from day 1 to 20, such that on day 20, amplitude was greater than for control and antagonist-treated rams. Amplitude of $\mathrm{T}$ pulses in rams treated with GnRH antagonist increased from day 1 to 20, but tended to be lower than control rams on day 30 and were lower on day 40 after treatment.

\subsubsection{Bulls}

On day 21 of treatment (Table 3), both mean (5.7-fold) and basal (19-fold) concentrations of T were increased by treatment with GnRH agonist. These values were decreased by treatment with GnRH antagonist to 14 and $45 \%$ of control values, respectively. No pulses were detected in bulls treated with GnRH antagonist. Number of pulses was minimal in bulls treated with agonist, and the amplitude of pulses detected was only $49 \%$ of control values.

In bulls treated with GnRH agonist, both mean and basal concentrations of T decreased rapidly after cessation of treatment (Table 6) in such a way that by day 10 and thereafter, T concentrations were not different from control bulls. Bulls treated with GnRH antagonist had lesser mean and basal T concentrations on day 1, compared with bulls in the other groups. Mean T concentration in bulls previously treated with antagonist was greater than in control bulls on day 20 and tended to be greater on days 30 and 40. Basal concentration of $\mathrm{T}$ was greater in bulls treated with antagonist on day 10 and 40 after treatment, compared with control bulls. 
Table 6

Averages $( \pm$ S.E.M.) for variables of testosterone secretion in bulls on days 1-40 after the discontinuation of treatment

\begin{tabular}{cllllc}
\hline Day & Treatment ${ }^{\mathrm{a}}$ & Mean $(\mathrm{ng} / \mathrm{ml})$ & Basal $(\mathrm{ng} / \mathrm{ml})$ & $\begin{array}{l}\text { Pulse frequency } \\
\text { (pulses } / 24 \mathrm{~h})\end{array}$ & $\begin{array}{l}\text { Pulse amplitude } \\
(\mathrm{ng} / \mathrm{ml})\end{array}$ \\
\hline 1 & & & $3.25 \pm 0.48 \mathrm{e}$ & $9.08 \pm 1.10 \mathrm{e}$ \\
& Control & $2.71 \pm 0.25 \mathrm{f}$ & $0.78 \pm 0.07 \mathrm{f}$ & $1.00 \pm 0.71 \mathrm{f}$ & $3.66 \pm 0.94 \mathrm{f}$ \\
& Agonist & $6.72 \pm 0.61 \mathrm{e}$ & $6.53 \pm 1.78 \mathrm{e}$ & $1.00 \pm 0.58 \mathrm{f}$ & $1.09 \pm 0.27 \mathrm{f}$ \\
10 & Antagonist & $0.33 \pm 0.08 \mathrm{~g}$ & $0.25 \pm 0.05 \mathrm{~g}$ & $8.95 \pm 1.35 \mathrm{e}$ \\
& Control & $3.64 \pm 0.47 \mathrm{j}, \mathrm{k}$ & $1.07 \pm 0.30 \mathrm{~b}$ & $4.25 \pm 1.03$ & $8.74 \pm 0.62 \mathrm{e}$ \\
& Agonist & $3.27 \pm 0.50 \mathrm{k}$ & $0.91 \pm 0.12 \mathrm{~b}$ & $4.75 \pm 0.95$ & $3.08 \pm 0.34 \mathrm{f}$ \\
20 & Antagonist & $4.86 \pm 0.78 \mathrm{j}$ & $4.46 \pm 0.91 \mathrm{a}$ & $3.25 \pm 0.85$ & $9.08 \pm 2.15$ \\
& Control & $3.10 \pm 0.29 \mathrm{f}$ & $1.10 \pm 0.21 \mathrm{j}, \mathrm{k}$ & $3.25 \pm 0.48 \mathrm{f}$ & $9.54 \pm 1.03$ \\
& Agonist & $3.03 \pm 0.28 \mathrm{f}$ & $1.00 \pm 0.04 \mathrm{k}$ & $3.50 \pm 0.29 \mathrm{f}$ & $8.38 \pm 1.08 \mathrm{j}, \mathrm{k}$ \\
30 & Antagonist & $5.23 \pm 0.21 \mathrm{e}$ & $1.79 \pm 0.31 \mathrm{j}$ & $5.50 \pm 0.65 \mathrm{e}$ & $7.44 \pm 0.64 \mathrm{k}$ \\
& Control & $2.78 \pm 0.28 \mathrm{k}$ & $0.88 \pm 0.04$ & $3.00 \pm 0.41 \mathrm{k}$ & $10.97 \pm 1.77 \mathrm{j}$ \\
& Agonist & $2.77 \pm 0.30 \mathrm{k}$ & $0.90 \pm 0.11$ & $4.25 \pm 0.75 \mathrm{j}, \mathrm{k}$ & $8.43 \pm 1.65$ \\
& Antagonist & $4.29 \pm 0.41 \mathrm{j}$ & $1.05 \pm 0.13$ & $4.75 \pm 0.48 \mathrm{j}$ & $6.06 \pm 0.73$ \\
& Control & $2.68 \pm 0.15 \mathrm{k}$ & $0.87 \pm 0.02 \mathrm{f}$ & $3.25 \pm 0.75 \mathrm{f}$ & $7.64 \pm 1.89$
\end{tabular}

Means with different letters within variable and day are different or tend to be different: $(\mathrm{a}, \mathrm{b}) P<0.001 ;(\mathrm{e}, \mathrm{f}, \mathrm{g}) P<0.05$; (j,k) $P<0.1$.

a Bulls were treated for 28 days with vehicle (control), or with GnRH agonist, or GnRH antagonist ( $n=4$ at each day of evaluation).

Testosterone pulse frequency was less for both GnRH agonist- and antagonist-treated bulls on day 1 after treatment compared with control bulls. Bulls treated with GnRH antagonist had a greater $\mathrm{T}$ pulse frequency on days 20 and 40, and the difference also tended to occur on day 30 after treatment. Amplitudes of T pulses in GnRH agonist- and antagonist-treated bulls were similar to those of control bulls by days 10 and 20 after treatment, respectively.

\subsection{FSH concentrations}

\subsubsection{Rams}

Mean concentration of FSH in rams was not different among groups on day 21 of treatment (Table 7). After cessation of treatment, interaction of treatment $\times$ day was significant. On day 1, FSH concentration in control rams was greater than in rams treated with GnRH antagonist. Concentration of FSH in rams treated with GnRH agonist was greater than in control rams on day 40 , and in rams treated with GnRH antagonist from day 10 to 30.

\subsubsection{Bulls}

On day 21 of treatment, mean FSH concentration in bulls (Table 7) was less in bulls treated with GnRH antagonist than in control bulls. After the discontinuation of treatments, the interaction of treatment $\times$ day was significant. Mean FSH concentration was less on days 10, 20, and 30 and tended to be less on days 1 and 40 in bulls treated with GnRH agonist compared with control bulls. Concentration of FSH in bulls treated with GnRH antagonist tended to be less than in control bulls only on day 1 . 
Table 7

Means ( \pm S.E.M.) concentrations of FSH (ng/ml) in rams and bulls on day 21 of treatment and on days $1-40$ post-treatment

\begin{tabular}{|c|c|c|c|c|c|c|c|}
\hline \multirow[t]{2}{*}{ Species } & \multirow[t]{2}{*}{ Treatment $^{\mathrm{a}}$} & \multirow[t]{2}{*}{ Day 21 of treatment ${ }^{b}$} & \multicolumn{5}{|c|}{ Days after discontinuing treatment $\mathrm{c}^{\mathrm{c}}$} \\
\hline & & & 1 & 10 & 20 & 30 & 40 \\
\hline \multirow[t]{3}{*}{ Rams } & Control & $1.46 \pm 0.20$ & $1.88 \pm 0.33 \mathrm{e}$ & $1.77 \pm 0.14 \mathrm{e}, \mathrm{f}$ & $1.61 \pm 0.20 \mathrm{e}, \mathrm{f}$ & $1.68 \pm 0.28 \mathrm{e}, \mathrm{f}$ & $1.38 \pm 0.10 \mathrm{f}$ \\
\hline & Agonist & $1.41 \pm 0.05$ & $1.50 \pm 0.16 \mathrm{e}, \mathrm{f}$ & $2.02 \pm 0.13 \mathrm{e}$ & $1.89 \pm 0.13 \mathrm{e}$ & $2.12 \pm 0.21 \mathrm{e}$ & $1.91 \pm 0.18 \mathrm{e}$ \\
\hline & Antagonist & $1.38 \pm 0.09$ & $1.27 \pm 0.11 \mathrm{f}$ & $1.52 \pm 0.17 \mathrm{f}$ & $1.38 \pm 0.12 \mathrm{f}$ & $1.34 \pm 0.08 \mathrm{f}$ & $1.44 \pm 0.14 \mathrm{e}, \mathrm{f}$ \\
\hline \multirow[t]{3}{*}{ Bulls } & Control & $1.88 \pm 0.16 \mathrm{e}$ & $2.00 \pm 0.31 \mathrm{j}$ & $2.20 \pm 0.36 \mathrm{e}$ & $2.34 \pm 0.35 \mathrm{e}$ & $2.24 \pm 0.34 \mathrm{e}$ & $2.25 \pm 0.32 \mathrm{j}$ \\
\hline & Agonist & $1.71 \pm 0.06 \mathrm{e}, \mathrm{f}$ & $1.41 \pm 0.08 \mathrm{k}$ & $1.44 \pm 0.09 \mathrm{f}$ & $1.44 \pm 0.11 \mathrm{f}$ & $1.53 \pm 0.11 \mathrm{f}$ & $1.66 \pm 0.10 \mathrm{k}$ \\
\hline & Antagonist & $1.44 \pm 0.10 \mathrm{f}$ & $1.45 \pm 0.13 \mathrm{k}$ & $1.83 \pm 0.24 \mathrm{e}, \mathrm{f}$ & $2.03 \pm 0.29 \mathrm{e}, \mathrm{f}$ & $1.93 \pm 0.16 \mathrm{e}, \mathrm{f}$ & $2.22 \pm 0.31 \mathrm{j}, \mathrm{k}$ \\
\hline
\end{tabular}

Means with different letters within day and species are different or tend to be different: (e,f) $P<0.05 ;(\mathrm{j}, \mathrm{k}) P<0.1$.

${ }^{a}$ Rams and bulls were treated for 28 days with vehicle (control), or with GnRH agonist, or GnRH antagonist.

b $n=8$.

c $n=4$ at each day of evaluation. 
Rams
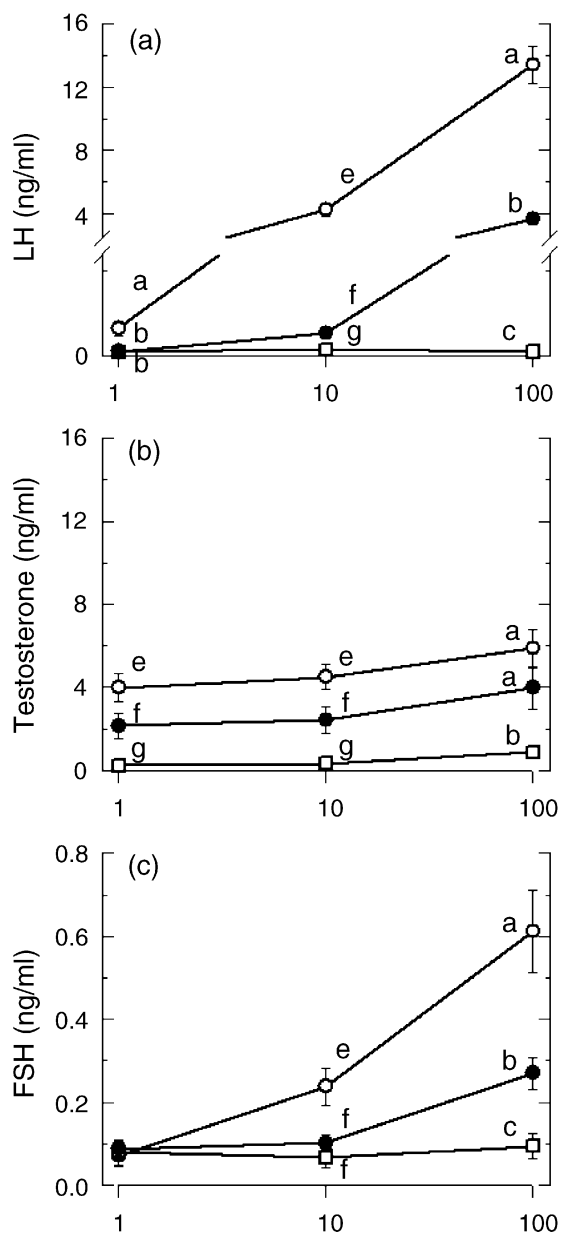
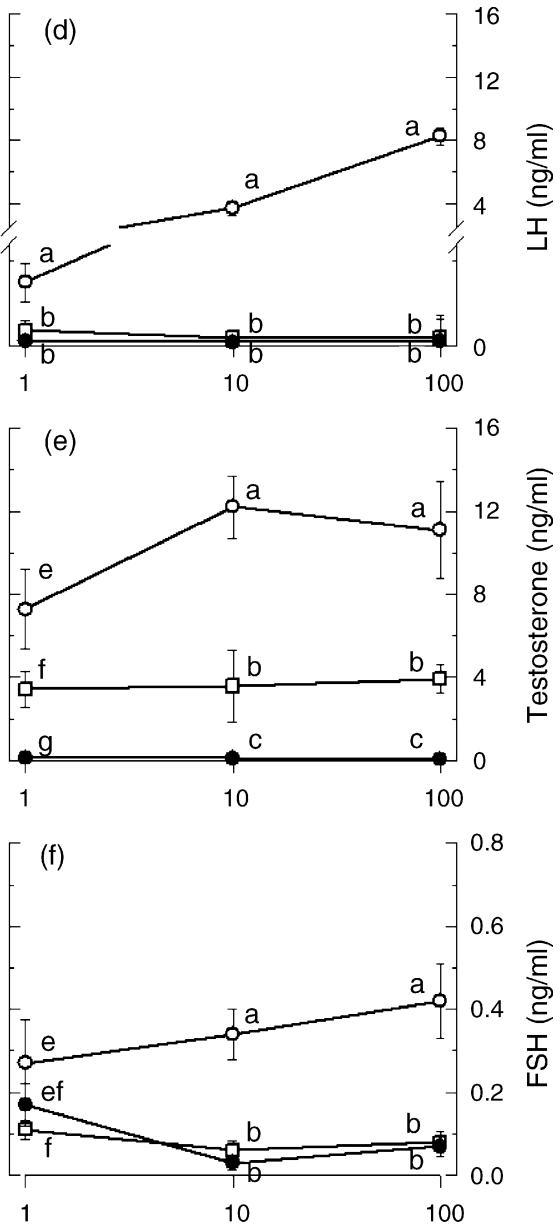

Dose ( $\mathrm{ng} \mathrm{GnRH/kg} \mathrm{body} \mathrm{weight)}$

Fig. 2. Mean ( \pm S.E.M.) amplitude of the response ( $\Delta$ values, $\mathrm{ng} / \mathrm{ml}$ ) of $\mathrm{LH}$, testosterone and FSH in rams (panels a-c) and bulls (panels $\mathrm{d}-\mathrm{f}$ ) to different doses (i.v. administration) of natural sequence $\mathrm{GnRH}$ on days 22 ( $1 \mathrm{ng} / \mathrm{kg}$ body weight), $24(10 \mathrm{ng} / \mathrm{kg}$ body weight), and $26(100 \mathrm{ng} / \mathrm{kg}$ body weight $)$ of the treatment period. Rams and bulls were treated with vehicle (control; open circles), or with GnRH agonist (open squares), or GnRH antagonist (closed circles) for 28 days. Different superscripts within hormone and dose denote a significant difference (a,b,c: $P<0.001$; e,f,g: $P<0.05$ ) between treatments ( $n=8$ at each time point).

\subsection{Responses to exogenous GnRH during treatment}

\subsubsection{Rams}

With regard to concentrations of $\mathrm{LH}$, control rams responded to all different doses of $\mathrm{GnRH}$ in a dose-related fashion (Fig. 2a); testosterone response was the same regardless of the GnRH dose (Fig. 2b), while for FSH (Fig. 2c) a significant release was detected only with the 10 and $100 \mathrm{ng} / \mathrm{kg}$ BW doses. Rams treated with $\mathrm{GnRH}$ agonist failed to 
show an LH, FSH, or T response to all doses of GnRH (Fig. 2a-c). Significant LH, $\mathrm{FSH}$, and $\mathrm{T}$ release occurred in rams treated with $\mathrm{GnRH}$ antagonist in response to 10 and $100 \mathrm{ng} \mathrm{GnRH} / \mathrm{kg} \mathrm{BW}$ (Fig. 2a-c). The respective releases of hormones were always less than in control rams. At $1 \mathrm{ng} \mathrm{GnRH} / \mathrm{kg} \mathrm{BW}$, there was no significant $\mathrm{LH}$ increase detected $(0.09 \mathrm{ng} / \mathrm{ml})$ in rams treated with $\mathrm{GnRH}$ antagonist but the relatively minor LH response that did occur was biologically significant as assessed by the corresponding consistent increase of $2.15 \mathrm{ng} \mathrm{T} / \mathrm{ml}$.

\subsubsection{Bulls}

In control bulls, the amplitude of $\mathrm{LH}$ release after $\mathrm{GnRH}$ administration occurred in a doserelated fashion (Fig. 2d). For T, the greatest amplitude in response to $\mathrm{GnRH}$ occurred after the $10 \mathrm{ng} / \mathrm{kg} \mathrm{BW}$ dose, which was different from the response to the $1 \mathrm{ng}$ dose (Fig. 2e) while FSH release was not different among doses (Fig. 2f). Bulls treated with GnRH antagonist failed to show an LH, FSH and T response to all doses of GnRH (Fig. 2d-f). Treatment with GnRH agonist inhibited the release of LH and FSH after administration of all doses of GnRH (Fig. 2d and f). A significant increase of more than $3 \mathrm{ng} \mathrm{T} / \mathrm{ml}$ was detected in bulls treated with $\mathrm{GnRH}$ agonist after all doses of GnRH (Fig. 2e). These increases in T occurred in the absence of any apparent corresponding increases in LH.


Fig. 3. Secretory profiles (absolute values; mean \pm S.E.M.) of LH (panels a-e), testosterone (panels f-j), and FSH (panels $\mathrm{k}-\mathrm{o}$ ) in rams, in response to an i.v. administration of $100 \mathrm{ng}$ of natural sequence $\mathrm{GnRH} / \mathrm{kg}$ body weight on days 1 , 10, 20, 30, and 40 after the discontinuation of treatment. Rams were treated with vehicle (control; open circles), or with GnRH agonist (open squares), or GnRH antagonist (closed circles) for 28 days ( $n=4$ at each time point). 


\subsection{Responses to exogenous GnRH after treatment}

\subsubsection{Rams}

The patterns of hormonal release after administration of $100 \mathrm{ng} \mathrm{GnRH} / \mathrm{kg} \mathrm{BW}$ in rams during the period after treatment with GnRH analogs are depicted in Fig. 3. Data regarding the amplitude of such releases are included in Table 8. On day 1 after treatments, rams treated with GnRH agonist had the least amplitude of LH release (Table 8 and Fig. 3a). Although the change in LH in rams treated with GnRH agonist did not differ from zero, there was a significant increase in T concentration (Table 8 and Fig. 3f). From day 10 to 40, the amplitudes of LH and T release in the agonist-treated group were not different from the control group, except on day 20, when amplitude of $\mathrm{T}$ was greater in the agonist compared with the control group. Rams treated with $\mathrm{GnRH}$ antagonist recovered rapidly in their ability to respond to GnRH, such that by day 1 after treatment, $\mathrm{LH}$ and $\mathrm{T}$ amplitude of release after administration of GnRH was not different from control rams (Table 8 and Fig. 3a and f). Furthermore, in the antagonist group, LH release after administration of GnRH was as much as 2.4 times greater compared with control rams from day 10 to 40, and T amplitude was greater on day 20 and tended to be so on day 10 after treatment. Hormone concentration values for each ram during the $6 \mathrm{~h}$ following $\mathrm{GnRH}$ administration were averaged and taken as an estimate of the total amount of hormone released in response to GnRH administration (data not shown). When data were evaluated in this manner, the antagonist group had the greatest response from days 10 to 40 for both LH and T, and the agonist group had the least $\mathrm{LH}$ response on days 30 and 40. Amplitude of FSH release after administration of GnRH (Table 8 and Fig. 3k-o) in rams treated with GnRH agonist was greater than in control rams on day 10 and tended to be so on day 20 .

Table 8

Averages ( \pm S.E.M.) amplitude of the response ( $\Delta$ values; $\mathrm{ng} / \mathrm{ml}$ ) of $\mathrm{LH}$, testosterone, and FSH in rams to an i.v. administration of $100 \mathrm{ng}$ of natural sequence $\mathrm{GnRH} / \mathrm{kg}$ body weight, on days 1, 10, 2030 , and 40 after the discontinuation of treatment

\begin{tabular}{clrcc}
\hline Day & Treatment $^{\mathrm{a}}$ & \multicolumn{1}{l}{ LH } & Testosterone & FSH \\
\hline 1 & Control & $11.86 \pm 3.09 \mathrm{e}$ & $5.63 \pm 1.12 \mathrm{e}$ & $0.61 \pm 0.12$ \\
& Agonist & $1.20 \pm 1.01 \mathrm{f}$ & $2.80 \pm 1.17 \mathrm{f}$ & $0.26 \pm 0.13$ \\
& Antagonist & $12.32 \pm 0.89 \mathrm{e}$ & $4.24 \pm 0.47 \mathrm{e}, \mathrm{f}$ & $0.56 \pm 0.19$ \\
10 & Control & $12.78 \pm 2.54 \mathrm{f}$ & $5.93 \pm 0.35 \mathrm{k}$ & $0.88 \pm 0.15 \mathrm{f}$ \\
& Agonist & $17.11 \pm 2.41 \mathrm{f}$ & $7.57 \pm 0.61 \mathrm{j}, \mathrm{k}$ & $1.62 \pm 0.43 \mathrm{e}$ \\
& Antagonist & $31.14 \pm 3.20 \mathrm{e}$ & $8.30 \pm 0.79 \mathrm{j}$ & $1.30 \pm 0.17 \mathrm{e}, \mathrm{f}$ \\
20 & Control & $18.93 \pm 3.24 \mathrm{~b}$ & $4.50 \pm 0.65 \mathrm{f}$ & $1.03 \pm 0.18 \mathrm{k}$ \\
& Agonist & $20.60 \pm 4.41 \mathrm{~b}$ & $7.55 \pm 0.79 \mathrm{e}$ & $1.64 \pm 0.29 \mathrm{j}$ \\
& Antagonist & $36.03 \pm 6.21 \mathrm{a}$ & $10.15 \pm 0.62 \mathrm{e}$ & $1.06 \pm 0.25 \mathrm{k}$ \\
30 & Control & $19.11 \pm 2.41 \mathrm{~b}$ & $6.41 \pm 1.56 \mathrm{j}, \mathrm{k}$ & $1.02 \pm 0.17$ \\
& Agonist & $15.36 \pm 3.37 \mathrm{~b}$ & $4.47 \pm 0.91 \mathrm{k}$ & $0.96 \pm 0.13$ \\
& Antagonist & $45.50 \pm 5.30 \mathrm{a}$ & $6.87 \pm 1.09 \mathrm{j}$ & $1.20 \pm 0.36$ \\
& Control & $18.00 \pm 1.82 \mathrm{~b}$ & $6.73 \pm 0.55$ & $0.99 \pm 0.21$ \\
& Agonist & $13.32 \pm 1.85 \mathrm{~b}$ & $7.28 \pm 0.41$ & $0.74 \pm 0.12$ \\
& Antagonist & $34.65 \pm 3.04 \mathrm{a}$ & $8.53 \pm 1.62$ & $1.02 \pm 0.29$ \\
\hline
\end{tabular}

Means with different letters within hormone and day are different or tend to be different: (a,b) $P<0.001 ;(\mathrm{e}, \mathrm{f}) P<0.05$; (j,k) $P<0.1$.

${ }^{\text {a }}$ Rams were treated for 28 days with vehicle (control), or with GnRH agonist, or GnRH antagonist ( $n=4$ at each day of evaluation). 


\subsubsection{Bulls}

Due to technical problems in administering the $100 \mathrm{ng} / \mathrm{kg} \mathrm{BW}$ dose of GnRH during the posttreatment period, release of LH, T and FSH in response to this treatment could not be evaluated.

\section{Discussion}

Data in this study indicate that the acute release of LH, FSH, and T after administration of GnRH analogs is similar in rams and bulls; however, during the period of treatment, agonist-treated bulls maintain greater concentrations of LH relative to the control group for extended periods of time as compared with rams. Furthermore, in agreement with a previous report, the secondary increase in T concentration in bulls is much greater as compared to that of rams. The release of $\mathrm{T}$ in bulls is also more sustained than that observed in the acute response to the agonist, and is associated with greater basal (Jiménez-Severiano et al., 2003a) and no change in mean (Melson et al., 1986; Ronayne et al., 1993; Bergfeld et al., 1996) concentrations of LH. Experimental evidence indicates that chronic treatment with GnRH agonists in bulls enhances the steroidogenic capacity of the testes, in terms of increased amounts of StAR protein and steroidogenic enzymes (Aspden et al., 1998), and greater amounts of LH receptors (Melson et al., 1986). Changes in testicular function might be related to the increase in basal LH concentration found in the present and previous (Jiménez-Severiano et al., 2003a) studies. This assumption is supported by data in rats (Mendis-Handagama et al., 1998) in which continuous stimulation of testes for 14 days with LH induces hypertrophy and hyperplasia of Leydig cells, increased steroidogenesis, and enhancement of basal and LH-stimulated T secretion by Leydig cells in vitro. In rams, the GnRH agonist was expected to suppress $\mathrm{LH}$ and $\mathrm{T}$ concentrations at day 21 of treatment (Lincoln et al., 1986); however, mean concentrations of both hormones were not different from the control group and basal LH and T concentrations were greater. It is likely that if treatments were administered longer than 28 days, hormone concentrations would have been suppressed more effectively (Tilbrook et al., 1993), because at the end of treatments the trend of hormone concentration was still decreasing.

In agreement with previous studies in rams (Lincoln et al., 1986; Caraty et al., 1990) and bulls (Melson et al., 1986; Jiménez-Severiano et al., 2003a), treatment with the GnRH agonist affected the pulsatile secretion of LH and T, and the GnRH-induced secretion of LH and FSH during treatment, which demonstrates that chronic treatment with the agonist desensitizes the pituitary in rams and bulls in the same way as in other species (Labrie et al., 1980; Bint Akhtar et al., 1983; Schürmeyer et al., 1984). Desensitization of the pituitary in cattle has been associated with lesser numbers of GnRH receptors, lesser content of LH and FSH, and lesser steady state amounts of LH $\beta$ - and FSH $\beta$-subunit mRNAs (Melson et al., 1986; Aspden et al., 1996).

Differences among species in the response to continuous stimulation with GnRH, therefore, primarily occur with basal LH secretion. The molecular mechanisms associated with these differences are not understood, but might be related to the way in which continuous GnRH stimulation affects the mechanisms of regulated and constitutive release of gonadotropins. In this regard, agonist treatment might induce major differences among species in the intracellular association of gonadotropins to chromogranins and secretogranins in secretory granules; theses proteins have a relevant role on sorting gonadotropins for the different secretion pathways in the pituitary of several species and cell lines (Crawford and McNeilly, 2002; Crawford et al., 2002; Kim et al., 2002). Furthermore, possible differential effects of continuous GnRH stimulation on activin A synthesis and paracrine activity on the pituitary cannot be discarded, because this protein has also been involved in stimulating LH secretion through a constitutive, granin-independent pathway (Nicol 
et al., 2004). Additional species differences might be related to how continuous GnRH stimulation affects gonadotropin subunit mRNA stability (Weiss et al., 1992; Crawford and McNeilly, 2002).

Treatment with GnRH antagonist suppressed the number of LH and T pulses in bulls, but only decreased pulse amplitude in rams. The latter finding indicates that the dose of antagonist used in rams allowed some GnRH receptors at the pituitary to bind endogenous GnRH to induce $\mathrm{LH}$ release. It appears that the effect of the antagonist on episodic LH release depends on the dose used, as has previously been demonstrated in rams, in which a single large i.v. dose of the GnRH antagonist, RS-18286 (365 $\mu \mathrm{g} / \mathrm{kg} \mathrm{BW})$, suppressed pulses more effectively and for a longer period of time than a $6.1 \mu \mathrm{g} / \mathrm{kg}$ BW dose (Lincoln and Fraser, 1987).

Treatment with GnRH antagonist also had a differential effect in rams and bulls on the response to varying doses of GnRH. Rams receiving the antagonist responded to the two greatest doses of $\mathrm{GnRH}$. A similar release pattern after administration of $\mathrm{GnRH}$ has been reported in castrated rams (Caraty et al., 1990) and intact male cynomolgus monkeys (Weinbauer et al., 1992) treated with GnRH antagonist. In contrast, bulls did not respond to any dose of GnRH during the treatment with the antagonist. It appears that the pituitary in bulls is more sensitive to the effects of GnRH antagonist than the pituitary in rams, given that the dose of antagonist, based on body weight, was the same in both species. An alternative explanation is that, in terms of metabolic weight, bulls received a dose of the GnRH antagonist 56\% greater than rams; whether the different dose per kg metabolic weight might have influenced the response at the pituitary is not known.

The differential response of rams to the $\mathrm{GnRH}$ analogs reflects a probable difference in the mechanism of action of the agonist and antagonist. GnRH agonists desensitize the pituitary due to down-regulation of GnRH receptors and disruption of signal transduction pathways at the post-receptor level, leading to an impairment of gonadotropin synthesis and release (Huckle and Conn, 1988; Conn and Crowley, 1991). Hence, under the influence of agonist, even large doses of GnRH cannot induce gonadotropin secretion. In contrast, it appears that smaller doses of GnRH antagonist do not affect GnRH receptor population or signal transduction pathways in gonadotrope cells to the extent of the larger doses (Conn and Crowley, 1991; Csernus and Schally, 1992); therefore, amounts of GnRH sufficient to displace antagonist from GnRH receptors can override the antagonistic effect and induce the pituitary to respond (Caraty et al., 1990; Weinbauer et al., 1992; Li et al., 1994). Relatively large doses of cetrorelix in rats, however, can induce downregulation of GnRH receptors in a similar way as the treatment with GnRH agonists (Srkalovic et al., 1990; Pinski et al., 1996).

It is unlikely that the greater release of LH in response to supra-physiological doses of GnRH in rams previously treated with the antagonist is related to increased LH reserves in the pituitary. It is more likely that treatment with GnRH antagonist increased pituitary sensitivity to GnRH. Small doses of cetrorelix in male rats (24-48 $\mu \mathrm{g}$ /days) given in a constant releasable dose for 8 weeks can up-regulate GnRH receptors (Srkalovic et al., 1990; Bokser et al., 1991), even at 90 days after treatment (Bokser et al., 1991). Based on the latter data, the dose of cetrorelix used in the present study could have up-regulated GnRH receptors in the pituitary of rams. Under these conditions, and given that LH secretion by the pituitary is highly correlated with the number of GnRH receptors (Katt et al., 1985), once the negative effect of the antagonist ceased, the pituitary could release greater amounts of $\mathrm{LH}$.

In agreement with previous studies (Fraser and Lincoln, 1980; Lincoln et al., 1986), rams recovered to have normal patterns of $\mathrm{LH}$ and T release soon after cessation of treatment. Amplitude of $\mathrm{LH}$ and $\mathrm{T}$ releases in response to exogenous $\mathrm{GnRH}$ during the post-treatment period with GnRH agonist was, therefore, similar to that of control animals. In contrast, treatment with the agonist still had a negative effect on the total amount of LH released in response to GnRH at 
40 days after cessation of treatment. Previous reports in prepubertal bulls treated with a GnRH agonist indicated that $\mathrm{T}$ release after $\mathrm{GnRH}$ administration recovers by the second day after treatment cessation, and LH release does not fully recover by 20 days after cessation of treatment (Bergfeld et al., 1996). In the present study, the decrease in amplitude of naturally occurring LH pulses and the lesser concentrations of FSH indicate that the capacity of the pituitary to respond to endogenous GnRH is still impaired in bulls 40 days after discontinuing the treatment with agonist.

In summary, treatment with GnRH agonist suppressed endogenous LH pulses and pituitary response to exogenous $\mathrm{GnRH}$, and increased basal $\mathrm{LH}$ and $\mathrm{T}$ concentrations in rams and bulls but the magnitude of these responses was much greater and more prolonged in bulls than rams. Treatment with GnRH antagonist suppressed hormone concentrations, LH and T pulse frequency, and the response to exogenous GnRH in bulls to a greater extent than in rams. The capacity to release LH in response to exogenous (rams) and endogenous (bulls) GnRH recovered more rapidly after treatment with GnRH antagonist than with GnRH agonist. After the discontinuation of ana$\log$ treatment, rams previously treated with antagonist had an increased capacity of response to exogenous GnRH, while rams previously treated with agonist released lesser amounts of LH. Bulls previously treated with agonist had decreased LH pulse amplitudes and FSH concentrations, while bulls treated with antagonist had greater $\mathrm{T}$ concentrations and pulse frequencies after treatment.

\section{Conclusions}

The findings demonstrate that differences do occur between rams and bulls in LH, FSH and T secretion during and after treatment with GnRH analogs. Also, the effects of treatment with either agonist or antagonist on the pituitary-testis axis can persist for a considerable time after the discontinuation of treatment. The fundamental differences in the reproductive endocrine mechanisms involved in the differential response to continuous treatment with GnRH analogs among species remain to be elucidated, but might be related with the way in which the sorting mechanisms for regulated and constitutive release in the gonadotropes are affected.

\section{Acknowledgements}

The authors acknowledge Intervet International for providing the azagly-nafarelin; J.J. Reeves for the oLH antibody; L.E. Reichert for the oLH and oFSH for iodination; J.A. Dias for the oFSH antibody; G.D. Niswender for the T antibody; E. Grotjan, Jr. for use of the Four Fit program for analyzing RIA data; M. Miller, K. Pearson, D. Clopton and C. Toombs for technical assistance with the RIA's and sample collection; K. Moline, J. Bergman, and B. Browelit for their assistance with caring for the bulls and J. Osborne for assistance in editing and revising the manuscript. The academic program of H. Jiménez-Severiano was supported by the National Council for Science and Technology (CONACYT, Mexico), and the National Institute for Research in Forestry, Agriculture and Livestock (INIFAP, Mexico). This research is published as paper no. 14050, Journal Series Nebraska Agricultural Research Division and as paper 13-03AS, Ohio Agricultural Research and Development Center. Research supported by appropriated funds of the State of Nebraska. Mention of a trade name, proprietary product, or specific equipment does not constitute a guarantee or warranty by the USDA and does not imply its approval to the exclusion of other products that may be suitable. 


\section{References}

Aspden, W.J., Rao, A., Scott, P.T., Clarke, I.J., Trigg, T.E., Walsh, J., D’ Occhio, M.J., 1996. Direct actions of the luteinizing hormone-releasing hormone agonist, deslorelin, on anterior pituitary contents of luteinizing hormone (LH) and folliclestimulating hormone (FSH), LH and FSH subunit messenger ribonucleic acid, and plasma concentrations of LH and FSH in castrated male cattle. Biol. Reprod. 55, 386-392.

Aspden, W.J., Rodgers, R.J., Stocco, D.M., Scott, P.T., Wreford, N.G., Trigg, T.E., Walsh, J., D’Occhio, M.J., 1998. Changes in testicular steroidogenic acute regulatory (StAR) protein, steroidogenic enzymes and testicular morphology associated with increased testosterone secretion in bulls receiving the luteinizing hormone releasing hormone agonist deslorelin. Domest. Anim. Endocrinol. 15, 227-238.

Bergfeld, E.G.M., D’Occhio, M.J., Kinder, J.E., 1996. Continued desensitization of the pituitary gland in young bulls after treatment with the luteinizing hormone-releasing hormone agonist deslorelin. Biol. Reprod. 54, 769-775.

Bertschinger, H.J., Asa, C.S., Calle, P.P., Long, J.A., Bauman, K., DeMatteo, K., Jochle, W., Trigg, T.E., Human, A., 2001. Control of reproduction and sex related behaviour in exotic wild carnivores with the GnRH analogue deslorelin: preliminary observations. J. Reprod. Fertil. Suppl. 57, 275-283.

Bhasin, S., Swerdloff, R.S., 1986. Mechanisms of gonadotropin-releasing hormone agonist action in the human male. Endocr. Rev. 7, 106-114.

Bint Akhtar, F., Marshall, G.R., Wickings, E.J., Nieschlag, E., 1983. Reversible induction of azoospermia in rhesus monkeys by constant infusion of a gonadotropin-releasing hormone agonist using osmotic minipumps. J. Clin. Endocrinol. Metab. 56, 534-540.

Bokser, L., Srkalovic, G., Szepeshazi, K., Schally, A.V., 1991. Recovery of pituitary-gonadal function in male and female rats after prolonged administration of a potent antagonist of luteinizing hormone-releasing hormone (SB-75). Neuroendocrinology 54, 136-145.

Caraty, A., Locatelli, A., Delaleu, B., Spitz, I.M., Schatz, B., Bouchard, P., 1990. Gonadotropin-releasing hormone (GnRH) agonists and antagonists do not alter endogenous GnRH secretion in short-term castrated rams. Endocrinology 127, 2523-2529.

Conn, P.M., Crowley Jr., W.F., 1991. Gonadotropin-releasing hormone and its analogues. N. Engl. J. Med. 324, 93-103.

Crawford, J.L., McNeilly, A.S., 2002. Co-localisation of gonadotrophins and granins in gonadotrophs at different stages of the oestrous cycle in sheep. J. Endocrinol. 174, 179-194.

Crawford, J.L., McNeilly, J., Nicol, L., McNeilly, A.S., 2002. Promotion of intragranular co-aggregation with LH by enhancement of secretogranin II storage resulted in increased intracellular granule storage in gonadotrophs of GnRHdeprived male mice. Reproduction 124, 267-277.

Csernus, V.J., Schally, A.V., 1992. Evaluation of luteinizing hormone-releasing hormone antagonistic activity in vitro. Proc. Natl. Acad. Sci. U.S.A. 89, 5759-5763.

D’Occhio, M.J., Aspden, W.J., 1996. Characteristics of luteinizing hormone (LH) and testosterone secretion, pituitary responses to LH-releasing hormone (LHRH), and reproductive function in young bulls receiving the LHRH agonist deslorelin: effect of castration on LH responses to LHRH. Biol. Reprod. 54, 45-52.

D'Occhio, M.J., Aspden, W.J., 1999. Endocrine and reproductive responses of male and female cattle to agonists of gonadotrophin-releasing hormone. J. Reprod. Fertil. Suppl. 54, 101-114.

Dayalu, E., Kittok, R.J., 1996. Negative feedback on luteinizing hormone secretion requires infrequent exposure to testicular androgens. Anim. Reprod. Sci. 44, 55-69.

De Lean, A., Munson, P.J., Rodbard, D., 1978. Simultaneous analysis of families of sigmoidal curves: application to bioassay, radioligand assay, and physiological dose-response curves. Am. J. Physiol. 235, E97-E102.

Fraser, H.M., Lincoln, G.A., 1980. Effects of chronic treatment with an LHRH agonist on the secretion of LH, FSH and testosterone in the ram. Biol. Reprod. 22, 269-276.

Freking, B.A., Leymaster, K.A., Young, L.D., 2000. Evaluation of Dorset, Finnsheep, Romanov, Texel, and Montadale breeds of sheep. I. Effects of ram breed on productivity of ewes of two crossbred populations. J. Anim. Sci. 78, 1422-1429.

Herbert, C.A., Trigg, T.E., Renfree, M.B., Shaw, G., Eckery, D.C., Cooper, D.W., 2004. Effects of a gonadotropinreleasing hormone agonist implant on reproduction in a male marsupial, Macropus eugenii. Biol. Reprod. 70, 18361842.

Huckle, W.R., Conn, P.M., 1988. Molecular mechanism of gonadotropin releasing hormone action. II. The effector system. Endocr. Rev. 9, 387-395.

Jiménez-Severiano, H., D’Occhio, M.J., Lunstra, D.D., Mussard, M.L., Koch, J.W., Ehnis, L.R., Enright, W.J., Kinder, J.E., 2003a. Effect of chronic treatment with the gonadotrophin-releasing hormone agonist azagly-nafarelin on basal concentrations of LH in prepubertal bulls. Reproduction 125, 225-232. 
Jiménez-Severiano, H., Quintal-Franco, J., Vega-Murillo, V., Zanella, E., Wehrman, M.E., Lindsey, B.R., Melvin, E.J., Kinder, J.E., 2003b. Season of the year influences testosterone secretion in bulls administered luteinizing hormone. J. Anim. Sci. 81, 1023-1029.

Katt, J.A., Duncan, J.A., Herbon, L., Barkan, A., Marshall, J.C., 1985. The frequency of gonadotropin-releasing hormone stimulation determines the number of pituitary gonadotropin-releasing hormone receptors. Endocrinology 116 , 2113-2115.

Kim, T., Tao-Cheng, J.H., Eiden, L.E., Loh, Y.P., 2002. Large dense-core secretory granule biogenesis is under the control of chromogranin A in neuroendocrine cells. Ann. N.Y. Acad. Sci. 971, 323-331.

Labrie, F., Cusan, L., Séguin, C., Bélanger, A., Pelletier, G., Reeves, J.J., Kelly, P.A., Lemay, A., Raynud, J.P., 1980. Antifertility effects of LHRH agonists in the male rat and inhibition of testicular steroidogenesis in man. Int. J. Fertil. $25,157-170$.

Li, S.L., Vuagnat, B., Gruaz, N.M., Eshkol, A., Sizonenko, P.C., Aubert, M.L., 1994. Binding kinetics of the longacting gonadotropin-releasing hormone $(\mathrm{GnRH})$ antagonist antide to rat pituitary $\mathrm{GnRH}$ receptors. Endocrinology $134,45-52$.

Lincoln, G.A., Fraser, H.M., Abbott, M.P., 1986. Blockade of pulsatile LH, FSH and testosterone secretion in rams by constant infusion of an LHRH agonist. J. Reprod. Fertil. 77, 587-597.

Lincoln, G.A., 1987. Long-term stimulatory effects of a continuous infusion of LHRH agonist on testicular function in male red deer (Cervus elaphus). J. Reprod. Fertil. 80, 257-261.

Lincoln, G.A., Fraser, H.M., 1987. Compensatory response of the luteinizing-hormone (LH)-releasing hormone $(\mathrm{LHRH}) / \mathrm{LH}$ pulse generator after administration of a potent LHRH antagonist in the ram. Endocrinology 120, 2245-2250.

Littell, R.C., Milliken, G.A., Stroup, W.W., Wolfinger, R.D., 1996. SAS ${ }^{\circledR}$ System for Mixed Models. SAS Institute Inc., Cary, NC.

Melson, B.E., Brown, J.L., Schoenemann, H.M., Tarnavsky, G.K., Reeves, J.J., 1986. Elevation of serum testosterone during chronic LHRH agonist treatment in the bull. J. Anim. Sci. 62, 199-207.

Mendis-Handagama, S.M.L.C., Watkins, P.A., Gelber, S.J., Scallen, T.J., 1998. The effect of chronic luteinizing hormone treatment on adult rat Leydig cells. Tissue Cell 30, 64-73.

Merriam, G.R., Wachter, K.W., 1982. Algorithms for the study of episodic hormone secretion. Am. J. Physiol. 243, E310-E318.

Nicol, L., McNeilly, J., Stridsberg, M., McNeilly, A.S., 2004. Differential secretion of gonadotrophins: investigation of the role of secretogranin II and chromogranin A in the release of LH and FSH in LßT2 cells. J. Mol. Endocrinol. 32, 467-480.

Penfold, L.M., Ball, R., Burden, I., Jochle, W., Citino, S.B., Monfort, S.L., Wielebnowski, N., 2002. Case studies in antelope aggression control using GnRH agonist. Zool. Biol. 21, 435-448.

Peters, K.E., Bergfeld, E.G., Cupp, A.S., Kojima, F.N., Mariscal, V., Sanchez, T., Wehrman, M.E., Grotjan, H.E., Hamernik, D.L., Kittok, R.J., Kinder, J.E., 1994. Luteinizing hormone has a role in development of fully functional corpora lutea (CL) but is not required to maintain CL function in heifers. Biol. Reprod. 51, 1248-1254.

Pinski, J., Lamharzi, N., Halmos, G., Groot, K., Jungwirth, A., Vadillo-Buenfil, M., Kakar, S.S., Schally, A.V., 1996. Chronic administration of the luteinizing hormone-releasing hormone (LHRH) antagonist cetrorelix decreases gonadotrope responsiveness and pituitary LHRH receptor messenger ribonucleic acid levels in rats. Endocrinology $137,3430-3436$.

Ronayne, E., Enright, W.J., Roche, J.F., 1993. Effects of continuous administration of gonadotropin-releasing hormone $(\mathrm{GnRH})$ or a potent $\mathrm{GnRH}$ analogue on blood luteinizing hormone and testosterone concentrations in prepubertal bulls. Domest. Anim. Endocrinol. 10, 179-189.

SAS, 1990. SAS/STAT ${ }^{\circledR}$ User's Guide, Version 6. SAS Institute Inc, Cary, NC.

Schürmeyer, T., Knuth, U.A., Freuschem, C.W., Sandow, J., Bint Akhtar, F., Nieschlag, E., 1984. Suppression of pituitary and testicular function in normal men by constant gonadotropin-releasing hormone agonist infusion. J. Clin. Endocrinol. Metab. 58, 19-24.

Srkalovic, G., Bokser, L., Radulovic, S., Korkut, E., Schally, A.V., 1990. Receptors for luteinizing hormone-releasing hormone (LHRH) in dunning R3227 prostate cancers and rat anterior pituitaries after treatment with a sustained delivery system of LHRH antagonist SB-75. Endocrinology 127, 3052-3060.

Stumpf, T.T., Wolfe, M.W., Roberson, M.S., Kittok, R.J., Kinder, J.E., 1993. Season of the year influences concentration and pattern of gonadotropins and testosterone in circulation of the bovine male. Biol. Reprod. 49, 1089-1095.

Sundaram, K., Schmidt, F., Thau, R.B., Rivier, J.E., Vale, W., Bardin, C.W., 1984. Species differences in the sensitivity to the antitesticular effects of [Ac-D-NAL(2) ${ }^{1}, 4$ FD-Phe ${ }^{2}$, D-Trp ${ }^{3}$, D-Arg ${ }^{6}$ ]-LHRH antagonist. Contraception 29, 271-281. 
Tilbrook, A.J., Galloway, D.B., Williams, A.H., Clarke, I.J., 1993. Treatment of young rams with an agonist of GnRH delays reproductive development. Horm. Behav. 27, 5-28.

Vickery, B.H., McRae, G.I., 1980. Effects of continuous treatment of male baboons with superagonists of LHRH. Int. J. Fertil. 25, 179-184.

Vickery, B.H., McRae, G.I., Briones, W.V., Roberts, B.B., Worden, A.C., Schanbacher, B.D., Falvo, R.E., 1985. Dose-response studies on male reproductive parameters in dogs with nafarelin acetate, a potent LHRH agonist. J. Androl. 6, 53-60.

Wang, N.-G., Sundaram, K., Pavlou, S., Rivier, J.E., Vale, W., Bardin, C.W., 1983. Mice are insensitive to the antitesticular effects of luteinizing hormone-releasing hormone agonists. Endocrinology 112, 331-335.

Weinbauer, G.F., Hankel, P., Nieschlag, E., 1992. Exogenous gonadotrophin-releasing hormone (GnRH) stimulates LH secretion in male monkeys (Macaca fascicularis) treated chronically with high doses of a GnRH antagonist. J. Endocrinol. 133, 439-445.

Weiss, J., Crowley Jr., W.F., Jameson, J.L., 1992. Pulsatile gonadotropin-releasing hormone modifies polyadenylation of gonadotropin subunit messenger ribonucleic acids. Endocrinology 130, 415-420.

Wolfe, M.W., Stumpf, T.T., Roberson, M.S., Wolfe, P.L., Kittok, R.J., Kinder, J.E., 1989. Estradiol influences on pattern of gonadotropin secretion in bovine males during the period of changed responses to estradiol feedback in age-matched females. Biol. Reprod. 41, 626-634.

Xue, J.L., Dial, G.D., Bartsh, S., Kerkaert, B., Squires, E.J., Marsh, W.E., Ferre, G., 1994. Influence of a gonadotropinreleasing hormone agonist on circulating concentrations of luteinizing hormone and testosterone and tissue concentrations of compounds associated with boar taint. J. Anim. Sci. 72, 1290-1298. 